\title{
Macroalgae as a Valuable Source of Naturally Occurring Bioactive Compounds for the Treatment of Alzheimer's Disease
}

\author{
Tosin A. Olasehinde ${ }^{1,2,3, *}$, Ademola O. Olaniran ${ }^{4}$ and Anthony I. Okoh ${ }^{1,2}$ (I) \\ 1 Applied Environmental and Microbiology Research Group (AEMREG), Department of Biochemistry and \\ Microbiology, University of Fort Hare, Eastern Cape, Alice 5700, South Africa; aokoh@ufh.ac.za \\ 2 SAMRC Microbial Water Quality Monitoring Centre, University of Fort Hare, Eastern Cape, \\ Alice 5700, South Africa \\ 3 Nutrition and Toxicology Division, Food Technology Department, Federal Institute of Industrial Research, \\ Oshodi, Lagos PMB 21023, Nigeria \\ 4 Discipline of Microbiology, School of Life Sciences, College of Agricultural, Engineering and Science, \\ University of Kwazulu-Natal, Durban 4001, South Africa; Olanirana@ukzn.ac.za \\ * Correspondence: tosinolasehinde26@yahoo.com; Tel.: +27-810147782
}

Received: 20 September 2019; Accepted: 11 October 2019; Published: 25 October 2019

check for updates

\begin{abstract}
Alzheimer's disease (AD) is a neurological condition that affects mostly aged individuals. Evidence suggests that pathological mechanisms involved in the development of AD are associated with cholinergic deficit, glutamate excitotoxicity, beta-amyloid aggregation, tau phosphorylation, neuro-inflammation, and oxidative damage to neurons. Currently there is no cure for AD; however, synthetic therapies have been developed to effectively manage some of the symptoms at the early stage of the disease. Natural products from plants and marine organisms have been identified as important sources of bioactive compounds with neuroprotective potentials and less adverse effects compared to synthetic agents. Seaweeds contain several kinds of secondary metabolites such as phlorotannins, carotenoids, sterols, fucoidans, and poly unsaturated fatty acids. However, their neuroprotective effects and mechanisms of action have not been fully explored. This review discusses recent investigations and/or updates on interactions of bioactive compounds from seaweeds with biomarkers involved in the pathogenesis of $\mathrm{AD}$ using reports in electronic databases such as Web of science, Scopus, PubMed, Science direct, Scifinder, Taylor and Francis, Wiley, Springer, and Google scholar between 2015 and 2019. Phlorotannins, fucoidans, sterols, and carotenoids showed strong neuroprotective potentials in different experimental models. However, there are no data from human studies and/or clinical trials.
\end{abstract}

Keywords: Alzheimer's disease; seaweeds; cholinesterases; beta-secretase; beta-amyloid aggregation; neuroprotection

\section{Introduction}

Macroalgae, also known as seaweeds, are marine organisms and reservoirs of natural biologically active compounds. Different classes of macroalgae include rhodophyta (red algae), chlorophyta (green algae), and phaeophyta (brown algae). There are over 4000 red, 900 green, and 1500 brown species of macroalgae all over the world [1]. Most of the brown macroalgae are able to thrive in temperate and cool waters while green and red algal species exist in tropical and subtropical waters [1]. Several species of macroalgae thrive in their habitat at extreme conditions due to their capacity to develop defense mechanism via the release of some secondary metabolites. Historically, seaweeds have been used traditionally, especially in Asian countries, as herbal medicine for the treatment of tumors, urinary 
disease, gastrointestinal problems, cough, boils, hemorrhoid, ulcers, asthma, and headaches [2]. The appreciable levels of iodine in some edible seaweeds also make them a good choice for the treatment of goiter [3,4]. Specifically, species such as Ulva spp., Laminaria japonica, Porphyra spp., and Sargassum fusiforme have been used for the treatment of scrofula (cervical tuberculosis), edema, and goiter [3]. Furthermore, a combination of Ecklonia spp. and Sargassum spp. are used as herbs in Chinese medicine for the treatment of tumors, liver cirrhosis, and spleen enlargement [5]. Seaweeds are commonly consumed locally as vegetables and in salad. Some species of macroalgae are consumed as part of a staple diet because they are rich in functionally active compounds such as phenolic compounds, alkaloids, sterols, omega-6 fatty acids, antioxidants, carotenoids, and phenolic compounds [6]. They are also used as ingredients for dietary supplements, nutraceuticals, and pharmaceuticals. Some of the applications of some macroalgal species can be seen in their use as ingredients for the production of flavor, meat, cereal, and dairy products [7]. Much attention has been on marine macroalgae for the development of new drugs, nutraceuticals, and dietary supplements due to their beneficial effects as antioxidant [8], anti-tumor [9], anti-inflammatory [10], antidiabetic [11], anti-hypertensive [12], and antibacterial [13] agents. Evidence has shown that macroalgal-derived compounds are capable of improving learning and memory function in neurodegenerative conditions [14]. The neuroprotective effects of biologically active compounds from some macroalgae against neurodegenerative diseases has been described by Alghazwi et al. [15].

Alzheimer's disease (AD) is the most common form of dementia and has become a major health problem among aged individuals [16]. AD is characterized by cholinergic dysfunction, cognitive impairment, memory loss, neuronal death, and behavioral disturbances. The pathogenesis of AD involves complex mechanisms and impairment of the neurological cascade involved in memory function. The early onset of this disease has been diagnosed in persons less than 65 years. However, more than $90 \%$ of cases diagnosed are associated with the late onset of $\mathrm{AD}$ and this occurs mostly in individuals above 65 years of age [17]. The development of early onset AD has been linked with genetic mutations, especially genes that are responsible for $\mathrm{A} \beta$ peptide production (amyloid precursor protein (APP gene)), preselinin 1 (PS1), and preselinin 2 (PS2) genes [18]. Evidence has shown that dysregulation in the expression of these genes may account for about $5-10 \%$ of diagnosed cases of early onset AD [17,18]. Furthermore, apolipoprotein E (APO-E) polymorphic alleles has been identified as a major genetic risk factor for the development of early onset and late onset AD [19]. APO $\varepsilon 4$ alleles have been shown to trigger cognitive decline and cerebral amyloid angiopathy in aged individuals [20]. APOE is produced in astrocytes in the central nervous system, and it is important in the regulation of lipid homeostasis and beta-amyloid $(A \beta)$ metabolism. It also contributes to the formation of $A \beta$ plaques and development of cerebral amyloid angiopathy [21]. Furthermore, $\mathrm{APO} \varepsilon 4$ has also been linked to tau pathology [22]. The molecular mechanisms involved in the development of sporadic late onset of $\mathrm{AD}$ is not well known; however, previous reports have shown that it is linked to oxidative stress [23], loss of cholinergic signaling [24], accumulation of $A \beta$ plaques [25], and formation of neurofibrillary tangles [26]. Moreover, a recent report has shown that hyperphosphorylation of tau proteins is a major causative factor involved in the development and progression of AD [27]. Hence, recent research investigations are considering tau pathology as a therapeutic strategy for the management of AD. 
Previous experimental investigations have established that natural products could be effective in the management of Alzheimer's disease and have been suggested as an alternative therapeutic approach compared to synthetic agents [28-30]. The discovery of novel natural compounds from different species of marine macroalgae represents an important source of biologically active compounds with strong neuroprotective potentials. This present review report provides current knowledge on neuroprotective potentials of macroalgal-derived natural compounds and their effects on pathological mechanisms (oxidative stress-induced neurodegeneration, cholinergic dysfunction, and beta-secretase activities, as well as glutamate and metal-induced neurotoxicity and beta-amyloid aggregation) linked to Alzheimer's disease.

\section{Methods}

A literature search was done in different databases including Web of Science, Scopus, Scifinder, PubMed, Google scholar, Science direct, Springer, Taylor and Francis, and Wiley to identify reports published between 2015 and 2019 that are related to antioxidant activity and neuroprotective effects of macroalgal extracts and compounds as well as their modulatory effects on biomarkers linked with Alzheimer's disease. Articles revealing reports on the neuroprotective properties and modulatory effects of macroalgal extracts on biomolecules related to other neurodegenerative diseases such as Parkinson's disease, Huntington's disease, ischemia, and stroke were not considered in this study.

\section{Etiology of AD}

The occurrence of AD amongst aged individuals has been estimated to increase annually due to the complexity of its pathological mechanisms [31]. The etiology of AD is not well understood due to the multifactorial mechanisms underlying the disease process. Some of the factors that have been linked to the development and progression of $\mathrm{AD}$ include ageing, cholinergic deficit, $\mathrm{A} \beta$ aggregation, tau hyperphosphorylation, oxidative stress, neuro-inflammation, and diabetes. Figure 1 shows a complex cascade and set of mechanisms involving the development of AD. The cure for AD has not been discovered due to the complexity of the neuropathological mechanisms involved in the development and progression of the disease [32]. Fewer achievements have been attained in terms of effective treatment of the disease; however, much focus has been on early detection and prevention. Adequate diagnostic methods for $\mathrm{AD}$ is one of the challenging factors that has been encountered due to non-availability of reliable biomarkers. The current therapeutic approach used for the management of AD involves the use of cholinesterase inhibitors and the $\mathrm{N}$-methyl-d-aspartate receptor antagonist. These drugs do not have the capacity to halt the progression of the disease. Effective therapeutic agents or disease modifying drugs that are capable of stopping or preventing the clinical symptoms of AD are currently under extensive investigation [33,34]. However, seaweed-derived compounds have shown great potential as an alternative strategy for the management of AD (Figure 1). 


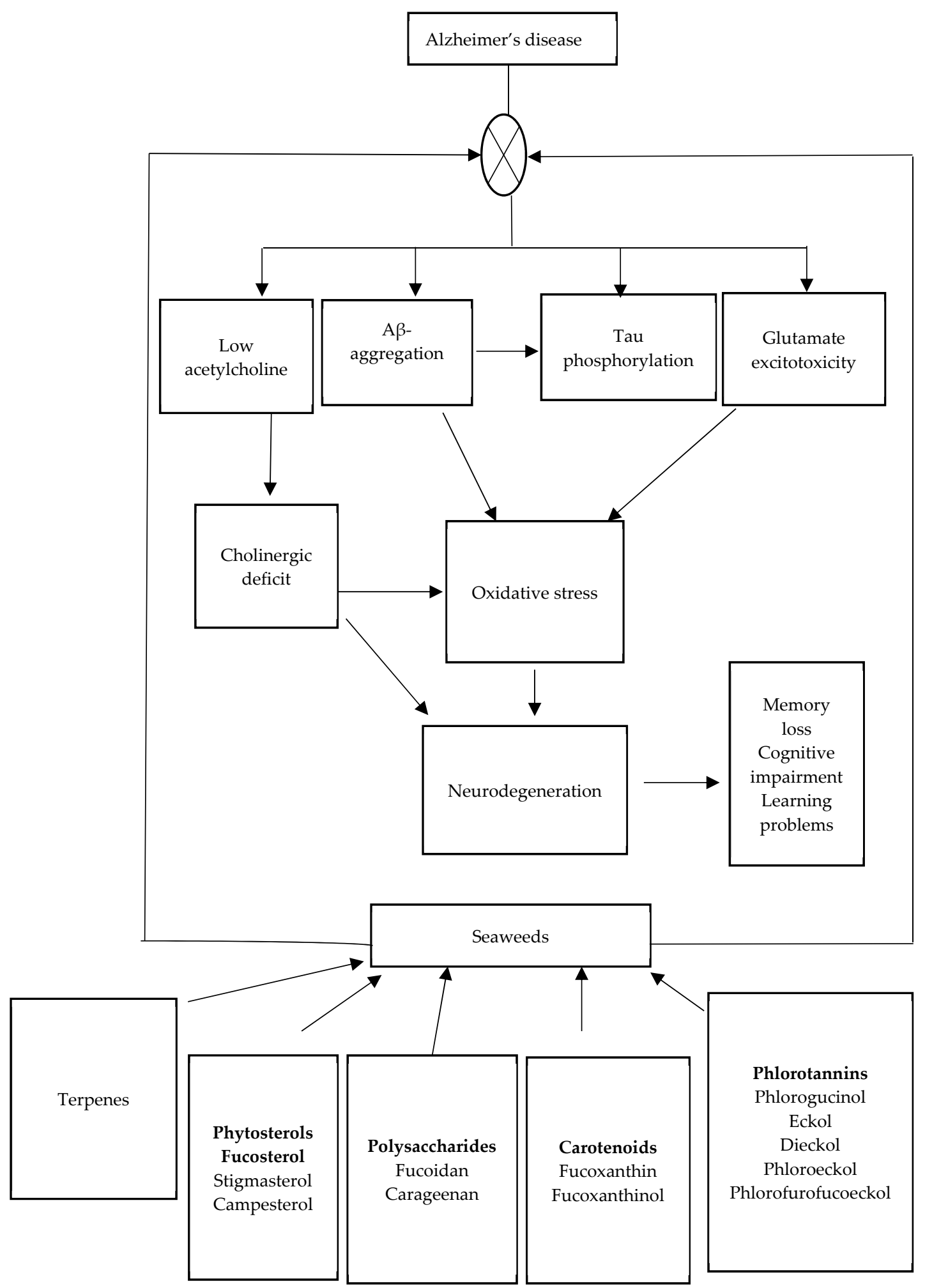

Figure 1. Mechanism of action of bioactive compounds from macroalgae against Alzheimer's disease.

\section{Therapeutic Role of Some Macroalgae in the Management of AD}

\subsection{Evidence from In Vitro Studies}

Some in vitro models have been used to determine the neuroprotective potentials of some macroalgal species against biomarkers of AD. Extracts derived from several species of macroalgae 
have been tested for their cholinesterase and beta-secretase (BACE-1) inhibitory activities. Neuronal cells have also been used as experimental models to determine the neuroprotective activities of macroalgal-derived compounds and extracts.

\subsubsection{Cholinesterase Inhibitory Activity}

Acetylcholinesterase (AChE) and butyrylcholinesterase (BChE) are important enzymes involved in the regulation of acetylcholine $(\mathrm{ACh})$ in the synaptic cleft of neurons to promote cognitive function $[35,36]$. However, loss or rapid degradation of acetylcholine leads to cholinergic dysfunction and ultimately memory impairment $[37,38]$. Hence, cholinesterases have been developed to alleviate cholinergic deficit by restoring ACh levels and improving cognitive function $[39,40]$. Seaweed-derived biologically active compounds have been reported to exhibit inhibitory effects on enzymes associated with Alzheimer's disease (Table 1). Results from some in vitro studies from our laboratory revealed that aqueous-ethanol extracts rich in phlorotannins, phenolic acids, and flavonoids from Ecklonia maxima, Gelidium pristoides, Gracilaria gracilis, and Ulva lactuca exhibit acetylcholinesterase and butyrylcholinesterase inhibitory activities [41]. Furthermore, sulfated polysaccharides obtained from Ulva rigida as well as the aforementioned algal species also showed potent inhibitory effects on BChE and AChE in vitro [42,43]. Purified fractions of Gelidiella acerosa showed AChE and BChE inhibitory activity [44]. Phytol was identified in the fraction as the most effective constituent. In the same study, molecular docking analysis revealed that phytol tightly binds to the arginine residue at the active site of the enzyme, thereby changing its conformation and exerting its inhibitory effect. Rengasamy et al. [45] reported AChE inhibitory activity of Codium duthieae, Amphiroa beauvoisii, Gelidium foliaceum, Laurencia complanata, and Rhodomelopsis africana. Hypnea musciformis and Ochtodes secundiramea extracts showed weak inhibitory activity (less than 30\% inhibition) on AChE. Jung et al. [46] also reported $\mathrm{AChE}$ and $\mathrm{BChE}$ inhibitory effects of methanol extracts of Ecklonia cava, Ecklonia kurome, and Myelophycus simplex. Glycoprotein isolated from Undaria pinnatifida showed dose responsive inhibitory effects on butyrylcholinesterase and acetylcholinesterase activities [47].

The $\mathrm{IC}_{50}$ values revealed that the glycoprotein exhibited higher inhibitory effect on $\mathrm{AChE}$ $(63.56 \mu \mathrm{g} / \mathrm{mL})$ than BChE $(99.03 \mu \mathrm{g} / \mathrm{mL})$. The enzyme inhibitory activities of the extracts were attributed to the presence of monoterpenes, which are reversible competitive inhibitors of the AChE. Shanmuganathan et al. [48] attributed the inhibitory effect of acetone extracts from P. gymnospora to alpha bisabolol.

In a recent study, fucosterol isolated from Sargassum horridum demonstrated potent inhibition against AChE activity [49]. Kinetic studies revealed that fucosterol showed competitive and non-competitive inhibition due to its high binding affinity to AChE compared to neostigmine. Choi et al. [50] reported that phlorofucofuroeckol isolated from Ecklonia cava exhibited potent inhibitory effects against BChE with an activity of over 100 fold higher than AChE inhibition.

\subsubsection{BACE-1 Inhibitory Activity}

BACE-1 has been identified as one of the prime therapeutic targets for the treatment of AD. It is a membrane-bound aspartyl protease that regulates $\mathrm{A} \beta$ production in the metabolism of amyloid precursor proteins. An increase in BACE-1 activity as well as elevated protein expression levels have been shown to trigger rapid production of $\mathrm{A} \beta$ protein and sporadic $\mathrm{AD}$ [51]. Cheng et al. [52] suggested that elevated levels of BACE-1 activity and increase in tumor necrosis factor (TNFa) expression may contribute to mild cognitive impairment and early events of AD. Furthermore, elevated BACE-1 activity also contributes to the increased number of plaques around the neurons and reduces cognitive ability of AD patients. High BACE-1 activity was also attributed to neurodegeneration and neurological decline in a transgenic mice model of AD [53]. The search for potent BACE-1 inhibitors has been a huge task as many inhibitors that have been developed have failed clinical tests. Some marine algal species have shown good potential as BACE-1 inhibitors (Table 1). Findings from our laboratory revealed that aqueous-ethanol extracts of G. pristoides, E. maxima, U. lactuca, 
and G. gracilis containing phlorotannins, flavonoids, and phenolic acids exhibited strong BACE-1 inhibitory activity with percentage inhibition of $97.2,83.3,86.9$, and $91.2 \%$ at the highest concentration $(120 \mu \mathrm{g} / \mathrm{mL})$ [41]. In another study, fucoidan, ulvan, and carrageenan obtained from E. maxima, U. lactuca, and G. pristoides also inhibited BACE-1 activity with percentage inhibition of 87.1, 71.2, and $51.3 \%$, respectively, at the highest concentration $(5.0 \mathrm{mg} / \mathrm{mL})$ [43]. Jung et al. [54] also reported the potency of fucosterol and fucoxanthin isolated from Undaria pinnatifida and Ecklonia stolonifera, respectively, against BACE- 1 activity. Fucoxanthin and fucosterol showed mixed and non-competitive types of inhibition, respectively, and their inhibitory activities were attributed to strong binding to hydroxyl groups of specific amino acid residues at the active site of the enzyme. Seong et al. [55] elucidated that monoterpenoids obtained from S. sagamianum exhibited potent BACE-1 inhibitory activity in vitro. The isolated compounds, saraquinoic and sargahydroquinoic acids, as well as sargachromenol interacted with the catalytic aspartyl residues and allosteric sites, thereby initiating tight binding to the enzyme, hence reducing its activity. Phlorofucofuroeckol isolated from E. cava also reduced BACE-1 activity [50]. Rafiquzzaman et al. [47] isolated and purified glycoproteins from Undaria pinnatifida and investigated their inhibitory effects on BACE-1 activity. The glycoprotein exhibited a dose dependent inhibitory effect on BACE-1. An insilico investigation on BACE-1 inhibitory potentials of glycyrrhizin and its metabolites isolated from Hizikia fusiformis revealed that $18 \alpha$-glycyrrhetinic acid and 18ß-glycyrrhetinic acid showed inhibitory effects against BACE-1 activity [56]. Moreover, $18 \beta$-glycyrrhetinic acid showed two-fold potent inhibitory activity compared with quercetin. The inhibitory activity of these compounds were attributed to their strong capacity to bind to the amino acid residues at the active site of BACE-1 via hydrogen bonds.

Table 1. Cholinesterase and beta-secretase inhibitory activities of macroalgal-derived extracts and isolated compounds.

\begin{tabular}{|c|c|c|c|c|}
\hline Class of Compounds & Components & Algal Source & Mechanism of Action & Reference \\
\hline \multirow{3}{*}{ Crude extracts } & $\begin{array}{l}\text { Benezene:ethyl acetate } \\
\text { fraction }\end{array}$ & G. acerosa & Inhibition of AChE & \\
\hline & \multirow[t]{2}{*}{ Methanol extracts } & $\begin{array}{l}\text { E. cava } \\
\text { E. kurome }\end{array}$ & $\begin{array}{l}\text { Inhibition of AChE and } \\
\text { BACE-1 }\end{array}$ & [44] \\
\hline & & M. simples & Inhibition of AChE & \\
\hline Phlorotannins & Phlorofucofuroeckol & E. cava & $\begin{array}{l}\text { Inhibition AChE, BChE, } \\
\text { and BACE-1 }\end{array}$ & [46] \\
\hline Polysaccharides & Purified glycoprotein & U. pinnatifida & $\begin{array}{l}\text { Inhibition of AChE, } \\
\text { BChE and BACE-1“ }\end{array}$ & [47] \\
\hline Sterol & Fucosterol & S. horridum & Inhibition of $\mathrm{AChE}$ & [49] \\
\hline Carotenoids & Fucoxanthin & $\begin{array}{l}\text { U. pinnatifida } \\
\text { E. stolonifera }\end{array}$ & Inhibition of BACE-1 & [54] \\
\hline \multirow[b]{2}{*}{ Triterpenoid-saponin } & Sarahydroquinoic acid & S. serratifolium & Inhibition of BACE-1 & [55] \\
\hline & $\begin{array}{c}\text { Glycyrrhizin } \\
18 \alpha \text {-glycyrrhetinic acid } \\
18 \beta \text {-glycyrrhetinic acid }\end{array}$ & H. fusiformis & $\begin{array}{l}\text { Inhibition of AChE, } \\
\text { BChE, and BACE-1 }\end{array}$ & [56] \\
\hline
\end{tabular}

\subsubsection{Action against Glutamate-Induced Neurotoxicity in Neuronal Cells}

Glutamate is an important neurotransmitter responsible for memory, learning, and cognitive function. However, excess levels of glutamate activate NMDA receptors and trigger the production of $A \beta$ peptide. Previous studies have highlighted two major pathways that trigger glutamate excitotoxicity; these include disruption of calcium homeostasis, which leads to the production of reactive oxygen species and neuronal death, as well as alterations in cysteine uptake due to high levels of glutamate [57]. This leads to imbalance of cystine homeostasis, limited levels of glutathione, and rapid production of reactive oxygen species. Hence, biologically active compounds capable of protecting the brain cells against glutamate excitotoxicity may be a good therapeutic intervention. 
Macroalgae are good sources of compound with the capacity to attenuate glutamate excitotoxicity in neuronal cells. Acetone extracts from two edible seaweeds (Saccahrina latissima and Fucus serratus) improved cell viability in glutamate-induced neurotoxicity in SH-SY5Y cells [58]. Phlorofucofuroeckol isolated from E. cava protected neurons against cell death, improved mitochondrial dysfunction, and regulated intracellular production of reactive oxygen species (ROS) in PC12 cells [59].

\subsubsection{Protection against A $\beta$-Induced Neurotoxicity}

Accumulation of $A \beta$ peptide is one of the hallmarks of $A D$ pathology. $A \beta$ is a pathogenic peptide released from amyloid precursor protein, which aggregates to form toxic plaques around the neurons [60]. Currently, no drug has been developed to combat $A \beta$ aggregation and its pathological processes in AD. Some species of macroalgae have been identified as potential sources of compounds capable of attenuating A $\beta$-induced neurotoxicity in AD models (Table 2).

Crude extracts of some algal species have been reported to inhibit amyloid formation and cause dis-aggregation of matured beta-amyloid fibrils [48,61,62]. In a study carried out by Alghazwi et al. [63], some species of Australian brown, green, and red algae attenuated A $\beta$-induced toxicity in PC12 cells. Fucosterol from Padina australis was evaluated for its neuroprotective effects in SH-SY5Y cells treated with $A \beta$ [64]. The result revealed that fucosterol ameliorated the neurotoxic effect of $A \beta$ and triggered the downregulation of APP expression. Alghazwi et al. [65] also reported the neuroprotective effects of fucoidans isolated from Undaria pinnatifida and Fucus vesiculosus via their inhibitory effect on $\mathrm{A} \beta$ aggregation and $\mathrm{A} \beta_{1-42}$-induced cytotoxicity in PC12 cells. In the same study, phlorotannins such as 7-phloroeckol, phlorofucofuroeckol, and dieckol also protected PC-12 cells against A $\beta$-induced neurotoxicity, reduced ROS production, and restored intracellular levels of $\mathrm{Ca}^{2+}$. However, dieckol exhibited moderately weak neuroprotective effects compared to 7-phloroeckol and phlorofucofuroeckol. Furthermore, phloroglucinol isolated from E. cava reduced ROS generation caused by A $\beta$-induced neurotoxicity in HT-22 cells [66]. Another unique phlorotannin (eckmaxol) isolated from E. maxima, also exhibited anti-amyloidogenic activity [67] (Table 2). Furthermore, fucoxanthin and fucosterol also attenuated amyloid oligomer-induced neurotoxicity in neuronal cell line models [68-70]. Wei et al. [71] also showed that fucoidan inhibited apoptosis in PC12 cells via activation of caspases, prevention of cytochrome c release, and upregulation of $X$-linked inhibitor of apoptosis (XIAP) in A $\beta$-induced PC-12 cells.

Table 2. Macroalgae extracts and compounds and inhibition of beta-amyloid-induced neurotoxicity.

\begin{tabular}{|c|c|c|c|c|}
\hline Class of Compounds & Components & Algal Source & Mechanism of Action & Reference \\
\hline \multirow{3}{*}{ Crude extracts } & Aqueous extracts & A. esculenta & \multirow{2}{*}{$\begin{array}{c}\text { Inhibition of amyloid formation } \\
\text { Anti-aggregation and dis-aggregation of amyloid } \\
\text { fibrils }\end{array}$} & {$[61]$} \\
\hline & Acetone extracts & P. gymnospora & & {$[48]$} \\
\hline & $\begin{array}{l}\text { Ether/benzene } \\
\text { extracts }\end{array}$ & G. acerosa & $\begin{array}{l}\text { Prevention of } A \beta_{25-35} \text { formation and } \\
\text { dis-aggregation of pre-formed fibrils }\end{array}$ & {$[62]$} \\
\hline \multirow{2}{*}{ Phlorotannins } & Phloroglucinol & E. cava & $\begin{array}{c}\text { Inhibition of A } \beta \text {-induced-cytotoxicity and } \\
\text { protection against ROS accumulation in HT- } 22 \text { cells }\end{array}$ & {$[64]$} \\
\hline & Eckmaxol & E. maxima & $\begin{array}{l}\text { Prevention of A } \beta \text {-induced neuronal apoptosis and } \\
\text { decrease in intracellular ROS }\end{array}$ & [67] \\
\hline \multirow[t]{2}{*}{ Phytosterol } & \multirow{2}{*}{ Fucosterol } & Padina australis & $\begin{array}{l}\text { Reduction of APP mRNA and inhibition of } \\
\text { A } \beta \text {-induced neurotoxicity }\end{array}$ & [64] \\
\hline & & E. stolonifera & Attenuation of $A \beta$-induced cognitive dysfunction & {$[68]$} \\
\hline \multirow{2}{*}{ Carotenoid } & \multirow{2}{*}{ Fucoxanthin } & \multirow{2}{*}{ Sargassum horneri } & $\begin{array}{l}\text { Attenuation of A } \beta \text {-oligomer-induced neurotoxicity } \\
\text { in SYH-SY5Y cells }\end{array}$ & [69] \\
\hline & & & $\begin{array}{l}\text { Attenuation of } \mathrm{A} \beta \text {-induced neurotoxicity in } \\
\mathrm{PC} 12 \text {-cells }\end{array}$ & [70] \\
\hline \multirow{2}{*}{ Sulfated polysaccharides } & \multirow{2}{*}{ Fucoidan } & U. pinnatifida & $\begin{array}{l}\text { Protection against } \mathrm{A} \beta_{1-42} \text {-induced neuronal death } \\
\text { in } \mathrm{PC}-12 \text { cells }\end{array}$ & [65] \\
\hline & & F. vesiculosus & $\begin{array}{c}\text { Inhibition of } \mathrm{A} \beta_{25-35} \text {-induced neurotoxicity in } \\
\text { PC-12 cells }\end{array}$ & {$[71]$} \\
\hline
\end{tabular}




\subsubsection{Antioxidant Activity of Macroalgae and AD}

Antioxidants have been identified as an effective therapeutic strategy for the delay of the progression of $\mathrm{AD}$. This is due to the fact that elevated levels of ROS in the brain are associated with the progression of $\mathrm{AD}$. Brain cells are highly susceptible to free radical attack due to high consumption of oxygen and lipid content as well as low antioxidant defense system. Hence, high levels of reactive oxygen species in brain cells may lead to lipid peroxidation, neurodegeneration, and ultimately cell death. Some species of macroalgae have been reported to exhibit neuroprotective effects via their antioxidant activities. Alghazwi et al. [15] reported the antioxidant activity of 49 compounds isolated from some brown, red, and green macroalgal species. Most of these compounds were identified as polysaccharides, phlorotannins, and terpenoids. Recent findings on the antioxidant activity of macroalgae revealed that some other algal species exhibit radical scavenging and metal chelating activities in vitro (Table 3 and Figure 2). Sathya et al. [72] reported the DPPH radical scavenging activity of methanol, ethylacetate, and dichloromethane extracts of Cystoseira trinodis with scavenging activity of 50\%, 54\%, and 69\% respectively. The ethyl acetate and butanol fractions of Sargassum fusiforme were also reported to exhibit radical scavenging activity [73]. Methanol extracts of some Gracilaria spp., Lesonia spp., Laminaria japonica, and Ascophyllum nodosum also exhibited DPPH and ABTS radical scavenging activities and ferric reducing properties $[74,75]$. Furthermore, acetone extracts from Ulva lactuca and Entermorpha intestinalis [76], and ethanol and hexane extracts from Pterocladiella capillacea and Osmindaria obtusiloba [77] including aqueous extracts from Ascophyllum nodosum, Bifurcaria bifurcate, and Fucus vesiculosus [78] also exhibited potent antioxidant activity via their radical scavenging activities, ferric reducing properties, and inhibition of lipid oxidation. The antioxidant activities of these algal extracts were attributed to the presence of phlorotannins. Pinteus et al. [79] reported the antioxidant activity of the methanol and dichloromethane extracts of $27 \mathrm{red}$, green, and brown macroalgal species through their oxygen radical antioxidant capacity and DPPH radical scavenging activity. The study showed that the methanol extracts of the brown algal species exhibited the highest antioxidant activities. Similarly, out of the hexane, ethyl acetate, and methanol extracts of seven algal species reported by Chiboub et al. [80], only Cytoseira sedoides (hexane, ethyl acetate, and methanol), Padina pavonica (ethyl acetate extract), Cladostephus spongiosum (ethylacetate and methanol), and Halopteris scoparia (methanol extract) exhibited DPPH and ABTS radical scavenging activity above $50 \%$.<smiles>Oc1cc(O)cc(O)c1</smiles>

Phloroglucinol

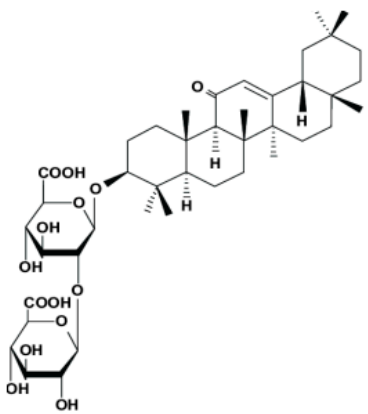

Glycyrrhizin

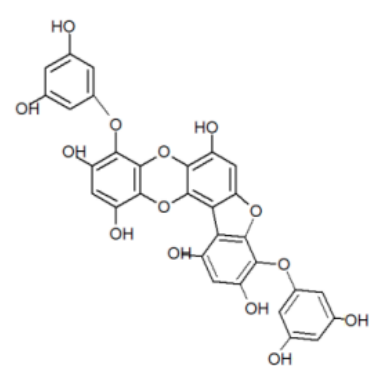

Phlorofucofuroeckol

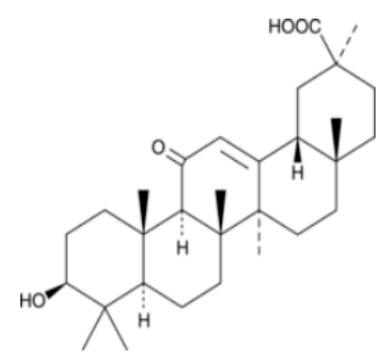

$18 \alpha$-glycyrrhetinic acid

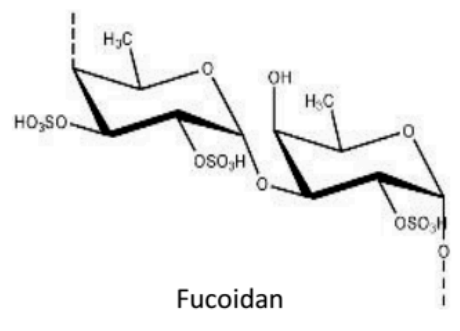

Fucoidan

Figure 2. Cont. 


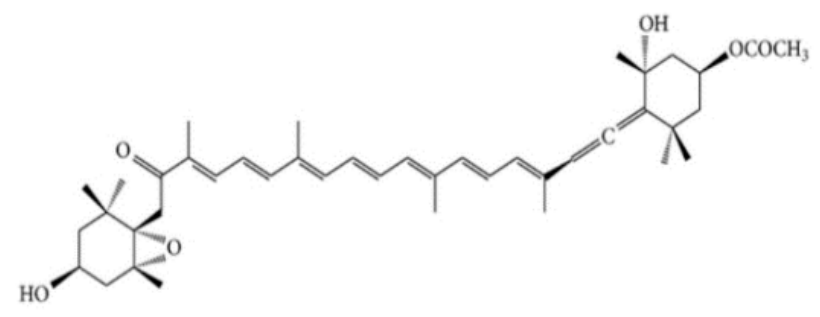

Fucoxanthin

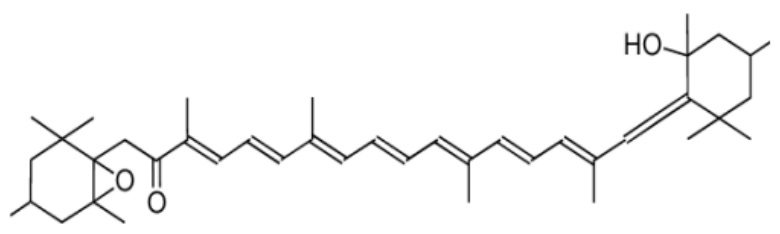

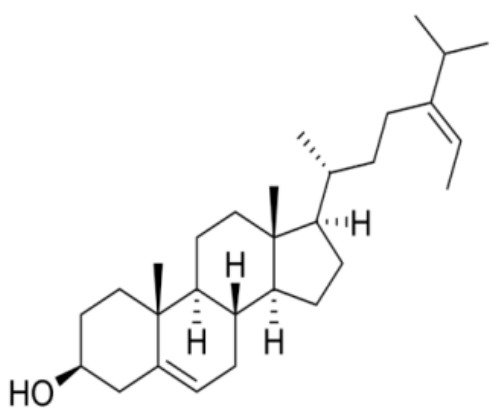

Fucosterol

\section{Fucoxanthinol}

Figure 2. Chemical structures of some neuroprotective compounds in marine seaweeds.

Crude fucoidans extracted from Sargassum sp. also exhibited antioxidant activity via their ferric reducing antioxidant properties and hydroxyl radical scavenging activities [81]. Purified fractions of $H$. elongata and Macrocytis pyrifera extracts exhibited antioxidant activity and this effect was attributed to the presence of phenolic terpenes, flavonoid derivatives, and phlorotannins [82,83]. Phenolic rich extracts from E. maxima, U. lactuca, U. rigida, G. gracilis, and G. pristoides also attenuated Zn-induced neurotoxicity and protected hippocampal neuronal cells (HT-22) against neuronal damage via inhibition of apoptosis, reduction of nitric oxide and malondialdehyde production, and improvement of antioxidant status $[84,85]$. The neuroprotective effects of the phenolic extracts could be linked to the radical scavenging and metal chelating activities of some of the bioactive constituents, which include phloroglucinol, ferulic acid, dihydroxybenzoic acid, 3,7-dimethyl quercetin, 5,7-dimethoxyflavone, dihydronaringenin-O-sulfate, apigenin, 7,2,4-trihydroxyisoflavanol, and kaempferol 3-(6-acetyl galactoside)7-rhamnose $[41,84,85]$. Polysaccharides such as fucoidans, alginates isolated from Sargassum spp., Laminaria japonica, Cystoseira trinodi, and Nizimuddinia zanardini [86-91], as well as protein extracts obtained from Ulva spp. and Gracilaria spp. [92] also showed potent radical scavenging activities. Furthermore, the report of Mohibbullah et al. [93] revealed that Porphyra yezoensis (an edible red alga) extracts induced synaptogenesis, increased neuronal survivability, and prevented neuronal death due to its radical scavenging ability. The neuroprotective effect of the extracts was attributed to taurine, an active component that improved neuronal development and maturation. Some studies also showed that carotenoids such as fucoxanthin and fucoxanthinol isolated from brown alga Himanthalia elongata [94], Sargassum horneri [95], and Undaria pinnatifida [96] exhibit neuroprotection via their antioxidant activity, as revealed by their radical scavenging activities, inhibition of apoptosis, intracellular reactive oxygen species and malondialdehyde production, attenuation of mitochondria membrane dysfunction, and DNA fragmentation. Glycoprotein isolated from $U$. pinnatifida increased superoxide dismutase and xanthine oxidase activities in hippocampal neuronal cells, which suggest its ability to prevent neurodegeneration [47]. Table 3 shows recent findings on the antioxidant activities of different classes of algal extracts and compounds. Antioxidant activity has been linked with neuroprotective effects due to the ability of antioxidants to suppress neurodegeneration, prevent neuronal death, and halt the progression of AD. Hence macroalgae are good sources of antioxidants with neuroprotective effects. 
Table 3. Antioxidant activity of macroalgal-derived extracts and compounds.

\begin{tabular}{|c|c|c|c|c|}
\hline Class of Compounds & Components & Algal Source & Mechanism of Action & Reference \\
\hline \multirow{10}{*}{ Crude extracts } & \multirow{5}{*}{ Methanol extract } & $\begin{array}{l}\text { Ascophyllum } \\
\text { nodosum }\end{array}$ & ABTS and DPPH scavenging activity & \multirow{2}{*}{ [74] } \\
\hline & & $\begin{array}{l}\text { Laminaria japonica } \\
\text { Lessonia trabeculate } \\
\text { Lessonia nigrescens }\end{array}$ & Ferric reducing antioxidant property & \\
\hline & & $\begin{array}{l}\text { Gracilaria edulis } \\
\text { Gracilaria corticata }\end{array}$ & $\begin{array}{l}\text { DPPH, ABTS, and NO radical scavenging } \\
\text { activities }\end{array}$ & [75] \\
\hline & & $\begin{array}{l}\text { Myelophycus } \\
\text { simplex }\end{array}$ & ABTS radical scavenging activity & \multirow{2}{*}{ [46] } \\
\hline & & $\begin{array}{l}\text { Ecklonia cava } \\
\text { E. kurome }\end{array}$ & $\begin{array}{l}\text { Attenuation of H202-induced oxidative } \\
\text { damage in SH-SY5Y cells }\end{array}$ & \\
\hline & \multirow{2}{*}{ Acetone extract } & Ulva lactuca & $\begin{array}{l}\text { DPPH and superoxide anion scavenging } \\
\text { activity }\end{array}$ & \multirow[t]{2}{*}{ [76] } \\
\hline & & $\begin{array}{l}\text { Entermorpha } \\
\text { intestinalis }\end{array}$ & Ferric reducing antioxidant property & \\
\hline & \multirow{2}{*}{$\begin{array}{l}\text { Ethanol/hexane } \\
\text { extract }\end{array}$} & $\begin{array}{l}\text { Pterocladiella } \\
\text { capillacea }\end{array}$ & DPPH radical scavenging activity & \multirow[t]{2}{*}{ [77] } \\
\hline & & $\begin{array}{l}\text { Osmindaria } \\
\text { obtusiloba }\end{array}$ & Metal chelating activity & \\
\hline & Aqueous extract & $\begin{array}{l}\text { Ascophyllum } \\
\text { nodosum } \\
\text { Bifurcaria bifurcate } \\
\text { Fucus vesiculosus }\end{array}$ & $\begin{array}{l}\text { DPPH, ABTS, and hydroxyl radical } \\
\text { scavenging activities } \\
\text { Ferric reducing antioxidant capacity } \\
\text { Inhibition of lipid oxidation }\end{array}$ & [78] \\
\hline Phlorotannins & $\begin{array}{l}\text { Phlorotannin } \\
\text { extract }\end{array}$ & Macrocytis pyrifera & DPPH radical scavenging activity & [83] \\
\hline \multirow{8}{*}{ Polysaccharides } & \multirow[t]{2}{*}{ Fucoidan } & $\begin{array}{l}\text { Sargassum } \\
\text { glaucescens }\end{array}$ & $\begin{array}{l}\text { ABTS and DPPH scavenging and metal } \\
\text { chelating activities }\end{array}$ & [85] \\
\hline & & $\begin{array}{l}\text { Sargassum } \\
\text { polycystum }\end{array}$ & $\begin{array}{l}\text { DPPH radical scavenging activity } \\
\text { Ferric reducing antioxidant property }\end{array}$ & [87] \\
\hline & $\begin{array}{l}\text { Fucoidan and } \\
\text { alginate }\end{array}$ & Cystoseira trinodis & Ferric reducing antioxidant property & [88] \\
\hline & $\begin{array}{l}\text { Fucoidan and } \\
\text { alginate }\end{array}$ & Sargassum latifolium & Hydroxyl radical scavenging activity & [89] \\
\hline & Sodium alginate & $\begin{array}{l}\text { Nizimuddinia } \\
\text { zanardini }\end{array}$ & DPPH radical scavenging activity & [90] \\
\hline & Polysaccharides & Laminaria japonica & $\begin{array}{l}\text { DPPH and oxygen radical scavenging } \\
\text { activity }\end{array}$ & [91] \\
\hline & \multirow{2}{*}{ Fucoidan } & \multirow{2}{*}{$\begin{array}{l}\text { U. pinnatifida } \\
\text { F. vesiculosus }\end{array}$} & $\begin{array}{l}\text { Attenuation of hydrogen } \\
\text { peroxide-induced oxidative stress and } \\
\text { apoptosis in PC-12 cells }\end{array}$ & [65] \\
\hline & & & $\begin{array}{l}\text { Activation of superoxide dismutase and } \\
\text { glutathione in A } \beta \text {-induced neurotoxicity } \\
\text { in PC-12 cells }\end{array}$ & [71] \\
\hline \multirow{2}{*}{ Proteins } & \multirow{2}{*}{ Protein extracts } & Ulva spp. & Ferric reducing antioxidant property & \multirow{2}{*}{ [92] } \\
\hline & & Gracilaria spp. & Oxygen radical absorption capacity & \\
\hline \multirow{4}{*}{ Carotenoids } & \multirow{3}{*}{ Fucoxanthin } & $\begin{array}{l}\text { Himanthalia } \\
\text { elongata }\end{array}$ & $\begin{array}{l}\text { Ferric reducing antioxidant property } \\
\text { DPPH radical scavenging activity }\end{array}$ & [94] \\
\hline & & \multirow[b]{2}{*}{ Sargassum horneri } & $\begin{array}{l}\text { Attenuation of } \mathrm{H}_{2} \mathrm{O}_{2} \text {-induced neuronal } \\
\text { apoptosis and intracellular ROS }\end{array}$ & [95] \\
\hline & & & $\begin{array}{l}\text { Reduced malondialdehyde levels and } \\
\text { SOD activity in A } \beta \text {-induced cell death in } \\
\text { PC12 cells }\end{array}$ & [70] \\
\hline & Fucoxanthinol & Undaria pinnatifida & $\begin{array}{l}\text { Attenuation of oxidative stress in rats' } \\
\text { hippocampal neurons }\end{array}$ & [96] \\
\hline
\end{tabular}




\subsection{Evidence from In Vivo Studies}

Neuroprotective effects of macroalgal extracts and compounds have been determined using different targets, which include oxidative stress, cholinergic function, beta-amyloid aggregation, apoptosis, and behavioral studies in in vivo models.

\subsubsection{Neuroprotective Activities of Some Macroalgal Extracts}

Crude extracts of some macroalgal species have shown neuroprotective potentials against some markers of Alzheimer's disease in vivo. Syad and Devi [97] confirmed that benzene extracts of G. acerosa attenuated neurotoxicity induced by $\mathrm{AB}_{25-35}$ in Swedish mice brain. G. acerosa improved memory function by attenuating cholinergic dysfunction via inhibition of acetylcholinesterase and butyrylcholinesterase. The extracts also inhibited BACE- 1 activity in vivo, hence suppressing A $\beta$ neurotoxicity. In the same study, G. acerosa extract protected mouse brain against lipid peroxidation and reduced caspase 3-activity and Bax expression, which suggest its effect against neuronal death. Acute and sub-acute toxicity experiments carried out on the benzene extract did not show any toxic effects on different organs in Swedish mice. Furthermore, a phlorotannin-rich fraction of Ishige foliacea, an edible brown seaweed, was reported to improve memory function in scopolamine-induced rat brain via reduction of lipid peroxidation, increase in superoxide dismutase activity and glutathione levels, as well as upregulation of brain-derived neurotrophic factors (BNDF), cyclic-AMP response binding protein (CREB), and phosphorylated extracellular signal regulated kinase (ERK) [98]. Choi et al. [99] found that ethanol extracts of $U$. pinnatifida improved cognitive dysfunction in mouse brain. The results of the study indicate that treatment with ethanol extracts of $U$. pinnatifida caused repairing effects in memory and restored spine density and morphology via increase in latency time in the passive avoidance test and dendritic spine in hippocampal neurons of scopolamine-induced rats. Similarly, fucoidan enhanced spatial learning and memory, which was impaired by infusion of D-galactose in mice brain [71]. In the same study, D-galactose reduced acetylcholine levels and choline acetyltransferase activity while acetylcholinesterase activity was significantly high, which suggests cholinergic dysfunction. However, treatment with fucoidan $(50 \mathrm{mg} / \mathrm{kg}$ ) reversed the levels of acetylcholine as well as choline acetyltransferase and acetylcholinesterase activities, which indicates an improvement in cholinergic function. Similarly, the neuroprotective effect of a fucoidan (SFPS65) isolated from Sargassum fusiforme was found in scopolamine and sodium nitrate-induced rats investigated by Hu et al. [100]. The authors suggested that SFPS65A improved stepdown latency, which was disrupted by scopolamine, and mitigated shock number and total wrong frequency. SFPS65A also attenuated spatial learning and memory dysfunction caused by ethanol and sodium in mice brain.

\subsubsection{Neuroprotective Effects of Macroalgal-Derived Compounds}

Several compounds have been identified and isolated from macroalgae; however, only few have been tested against biomarkers of $\mathrm{AD}$ in vivo. Fucoidan present brown alga showed neuroprotective A $\beta$-induced neurotoxicity in a transgenic Caenorhabditis elegans AD model [101]. The result of the study revealed that fucoidan reduced $A \beta$ accumulation by improving proteolysis and attenuation of $\mathrm{A} \beta$-induced ROS production Oh et al. [68] investigated the effect of fucosterol isolated from E. stolonifera on $A \beta$-induced cognitive dysfunction, again in rats. The study showed that fucosterol may enhance cognitive function in aging-induced endoplasmic reticulum stress and memory impairment. Fucosterol attenuated $\mathrm{A} \beta$-induced cognitive dysfunction via upregulation of BDNF-TRkB-ERK1/2 expression in rats' dentate gyrus. Lin et al. [102] evaluated the effect of fucoxanthin in scopolamine-induced memory impairment in rats' brains. Fucoxanthin reversed scopolamine-induced memory dysfunction via inhibition of acetylcholinesterase, and decrease in choline acetyltransferase activity and BDNF expression. Structure-activity analysis showed that fucoxanthin binds to the peripheral anionic site of AChE, hence decreasing the activity of the enzyme. Similarly, the study of Xiang et al. [103] revealed that fucoxanthin attenuated $A \beta$-induced cognitive impairment in mice brain. The inhibitory effects of 
fucoxanthin against $A \beta$ oligomerization and aggregation was attributed to its hydrophobic interaction with the peptide, hence preventing conformational transition and self-aggregation of the $A \beta$ peptide. Fucoxanthin also improved spatial learning and memory via the water maze tests and reversed the low levels of glutathione and superoxide dismutase and high levels of malondialdehyde in $A \beta$-induced mice. Furthermore, fucoxanthin activated the nuclear factor eythroid 2-related factor (NrF-2)-antioxidant response element (ARE) pathway and reversed upregulation of malondialdehyde and glutathione peroxidase activity in a rat model of traumatic brain injury, hence alleviating neurological deficits, neuronal apoptosis, brain lesion, and cerebral edema [104]. Yang et al. [66] reported that phloroglucinol isolated from E. cava attenuated cognitive deficit in mice brain. The study revealed that phloroglucinol may delay the onset or progression of AD due to its protective effects against the decrease in dendritic spine density, synaptophysin, and post synaptic density protein 95 (PSD-95). Yang et al. [105] also confirmed that oral administration of phloroglucinol improved impaired cognitive function in 5XFAD mice via reduction of 4-hydroxylnonenal, $\mathrm{A} \beta$ plaques, and pro-inflammatory cytokine production, as well as attenuation of glial reactivation.

\section{Conclusions}

This review provides evidence that macroalgae exhibit neuroprotective effects and could be important sources of biologically active compounds with therapeutic potential for the management of AD. Despite the identification of several macroalgal species and their various biological activities, only few have been explored for their neuroprotective effects against pathological mechanisms involved in Alzheimer's disease. The neuroprotective activities of some macroalgal-derived compounds and extracts via attenuation of cholinergic deficit, $A \beta$ aggregation, oxidative damage to neurons, and glutamate excitation, which have been established in recent findings, could be a significant approach for the management and treatment of AD. However, further investigations are needed to explore other species. Macroalgal extracts with potential neuroprotective activities should be characterized and purified, and their active constituents should be isolated. Further studies are also required to determine the mechanisms of action of macroalgal compounds and investigate their structure-activity relationship. Future research works on the neuroprotective effects of macroalgae may also focus on other targets linked with $\mathrm{AD}$ such as serotonin, somatostatin, tau hyperphosphorylation, neuro-inflammation, and metal-induced neurotoxicity, which have not been reported. Furthermore, most studies have shown in vitro neuroprotective effects of some algal species while in vivo experimental models are few. Further works should be done to determine the mechanism of action of macroalgal compounds in in vivo AD models. Compounds which have been established to exhibit neuroprotective effects in vivo, should be tested further in clinical trials.

Author Contributions: T.A.O. searched databases, reviewed the cited literature, and wrote the manuscript. T.A.O., A.O.O., and A.I.O. read and approved the final manuscript.

Funding: We are grateful to the National Research Foundation of South Africa, the World Academy of Science, and the South African Medical Research Council for financial support.

Conflicts of Interest: The authors declare no conflict of interest.

\section{References}

1. Rengasamy, K.R.; Kulkarni, M.G.; Stirk, W.A.; van Staden, J. Advances in algal drug research with emphasis on enzyme inhibitors. Biotechnol. Adv. 2014, 32, 1364-1381. [CrossRef]

2. Hong, D.D.; Hien, H.T. Nutritional analysis of Vietnamese seaweeds for food and medicineNo Title. Biofactors 2008, 22, 323-325. [CrossRef]

3. Chengkui, Z.; Tseng, C.; Junfu, Z.; Chang, C.F. Chinese seaweeds in herbal medicineNo Title. Hdrobiologia 1984, 116, 152-154. [CrossRef]

4. Niazi, A.K.; Kalra, S.; Irfan, A.; Islam, A. Thyroidology over the ages. Indian J. Endocrinol. Metab. 2011, 15, S121-S126. [CrossRef] [PubMed] 
5. Yang, Y. Chinese Herbal Medicines: Comparisons and Characteristicstle; Churchill Livingstone: London, UK, 2009; Volume 268.

6. Hamed, S.M.; El-Rhman, A.A.A.; Ibraheem, I.B.M. Role of marine macroalgae in plant protection \& improvement for sustainable agriculture technology. Beni-Suef Univ. J. Basic Appl. Sci. 2018, 7, 104-110.

7. Wells, M.I.; Potin, P.; Craigie, J.S.; Raven, J.A.; Merchant, S.S.; Helliwell, K.E.; Smith, A.G.; Camire, M.E.; Brawley, S.H. Algae as nutritional and functional food sources: Revisiting our understanding. J. Appl. Phycol. 2017, 29, 949-982. [CrossRef]

8. Kelman, D.; Posner, E.K.; McDermid, K.J.; Tabandera, N.K.; Wright, P.R.; Wright, A.D. Antioxidant activity of Hawaiian marine algae. Mar. Drugs 2012, 10, 403-416. [CrossRef]

9. Moussavou, G.; Kwak, D.H.; Obiang-Obonou, B.F.; Maranguy, C.A.; Dinzouna-Boutamba, S.; Lee, D.H.; Pissibanganga, O.G.M.; Ko, K.; Seo, J.I.; Choo, Y.K. Anticancer effects of different seaweeds on human colon and breast cancers. Mar. Drugs 2014, 12, 4898-4911. [CrossRef]

10. Riahi, C.R.; Tarhouni, S.; Kharrat, R. Screening of anti-inflammatory and analgesic activities in marines macroalgae from Mediterranean Sea. Arch. Inst. Pasteur Tunis 2011, 88, 19-28.

11. Zhao, C.; Yang, C.F.; Liu, B.; Lin, L.; Sarker, S.D.; Nahar, L.; Yu, H.; Cao, H.; Xiao, J. Bioactive compounds from marine macroalgae and their hypoglycemic benefits. Trends Foods Sci. Technol. 2018, 72, 1-12. [CrossRef]

12. Tierney, M.S.; Croft, A.K.; Hayes, M. A review of antihypertensive and antioxidant activities in macroalgae. Bot. Mar. 2010, 53, 387-408. [CrossRef]

13. Pérez, M.J.; Falque, E.; Domingue, H. Antimicrobial action of compounds from marine seaweed. Mar. Drugs 2016, 14, 52. [CrossRef] [PubMed]

14. Pangestuti, R.; Kim, S.K. Neuroprotective effects of marine algae. Mar. Drugs 2011, 9, 803-818. [CrossRef] [PubMed]

15. Alghazwi, M.; Kan, Y.Q.; Zhang, W.; Gai, W.P.; Garson, M.J.; Smid, S. Neuroprotective activities of natural products from marine macroalgae during 1999-2015. J. Appl. Phycol. 2016, 28, 3599-3616. [CrossRef]

16. Paris, D.; Beaulieu-Abdelahad, D.; Bachmeier, C.; Reed, J.; Ait-Ghezala, G.; Bishop, A.; Chao, J.; Mathura, V.; Crawford, F.; Mullan, M. Anatabine lowers Alzheimer's A $\beta$ production in vitro and in vivo. Eur. J. Pharmacol. 2011, 670, 384-391. [CrossRef] [PubMed]

17. Isik, A.T. Late onset Alzheimer's disease in older people. Clin. Interv. Aging 2010, 5, 307-311. [CrossRef]

18. Bekris, L.M.; Yu, C.; Bird, T.D.; Tsuang, T.W. Genetics of Alzheimer disease. J. Geriatr. Psychiatry Neurol. 2010, 23, 213-227. [CrossRef]

19. Yamazaki, Y.; Painter, M.M.; Bu, G.; Kanekiyo, T. Apolipoprotein E as a therapeutic target in Alzheimer's disease: A review of basic research and clinical evidence. CNS Drugs 2016, 30, 773-789. [CrossRef]

20. Liu, C.; Kanekiyo, T.; Xu, H.; Bu, G. Apolipoprotein E and Alzheimer disease: Risk, mechanisms, and Therapy. Nat. Rev. Neurol. 2013, 9, 106-118. [CrossRef]

21. Kim, J.; Basak, J.M.; Holtzman, D.M. The role of apolipoprotein E in Alzheimer's disease. Neuron 2009, 63, 287-303. [CrossRef]

22. Shi, Y.; Yamada, K.; Liddelow, S.A.; Smith, S.T.; Zhao, L.; Luo, W.; Tsai, R.M.; Spina, S.; Grinberg, L.T.; Rojas, J.C.; et al. ApoE4 markedly exacerbates tau-mediated neurodegeneration in a mouse model of tauopathy. Nature 2017, 549, 523-527. [CrossRef] [PubMed]

23. Zhao, Y.; Zhao, B. Oxidative stress and the pathogenesis of Alzheimer's disease. Oxid. Med. Cell. Longev. 2013, 2013, 316523. [CrossRef] [PubMed]

24. Haam, J.; Yakel, J.L. Cholinergic modulation of the hippocampal region and memory function. J. Neurochem. 2017, 142, 111-121. [CrossRef] [PubMed]

25. Sadigh-Eteghad, S.; Sabermarouf, B.; Majdi, A.; Talebi, M.; Farhoudi, M.; Mahmoudi, J. Amyloid-beta: A crucial factor in Alzheimer's disease. Med. Princ. Pract. 2015, 24, 1-10. [CrossRef] [PubMed]

26. Reas, X.E. Amyloid and tau pathology in normal cognitive aging. J. Neurosci. 2017, 37, 7561-7563. [CrossRef]

27. Kametani, F.; Hasegawa, M. Reconsideration of amyloid hypothesis and tau hypothesis in Alzheimer's disease. Front. Neurosci. 2018, 12, 25. [CrossRef]

28. Shal, B.; Ding, W.; Ali, H.; Kim, Y.S.; Khan, S. Anti-neuroinflammatory potential of natural products in attenuation of Alzheimer's disease. Front. Pharmacol. 2018, 9, 548. [CrossRef]

29. Olasehinde, T.A.; Olaniran, A.O.; Okoh, A. Therapeutic potentials of microalgae in the treatment of Alzheimer's disease. Molecules 2017, 22, 480. [CrossRef] 
30. Oboh, G.; Nwanna, E.E.; Oyeleye, S.I.; Olasehinde, T.A.; Ogunsuyi, O.B.; Boligon, A.A. In vitro neuroprotective potentials of aqueous and methanol extracts from Heinsia crinita leaves. Food Sci. Hum. Wellness 2016, 5, 95-102. [CrossRef]

31. Qui, C.; Kivipelto, M.; Strauss, E. Epidemiology of Alzheimer's disease: Occurrence, determinants, and strategies toward intervention. Dialogues Clin. Neurosci. 2009, 11, 111-128.

32. Graham, W.V.; Bonito-Oliva, A.; Sakmar, T.P. Update on Alzheimer's disease therapy and prevention strategies. Annu. Rev. Med. 2017, 68, 413-430. [CrossRef] [PubMed]

33. Yiannopoulou, K.G.; Papageorgiou, S.G. Current and future treatments for Alzheimer's disease. Ther. Adv. Neurol. Disord. 2013, 6, 19-33. [CrossRef] [PubMed]

34. Frozza, R.L.; Lourenco, M.V.; de Felice, F.G. Challenges for Alzheimer's disease therapy: Insights from novel mechanisms beyond memory defects. Front. Neurosci. 2018, 12, 37. [CrossRef] [PubMed]

35. Oboh, G.; Olasehinde, T.A.; Ademosun, A.O. Essential oil from lemon peels inhibit key enzymes linked to neurodegenerative conditions and pro-oxidant induced lipid peroxidation. J. Oleo Sci. 2014, 63, 373-381. [CrossRef] [PubMed]

36. Olasehinde, T.A.; Odjadjare, E.C.; Mabinya, L.V.; Olaniran, A.O.; Okoh, A.I. Chlorella sorokiniana and Chlorella minutissima exhibit antioxidant potentials, inhibit cholinesterases and modulate disaggregation of $\beta$-amyloid fibrils. Electron. J. Biotechnol. 2019, 40,1-9. [CrossRef]

37. Oboh, G.; Adewuni, T.M.; Ademosun, A.O.; Olasehinde, T.A. Sorghum stem extract modulates $\mathrm{Na}^{+} / \mathrm{K}^{+}$-ATPase, ecto-5'-nucleotidase, and acetylcholinesterase activities. Comp. Clin. Pathol. 2016, 25, 749-756. [CrossRef]

38. Oboh, G.; Oyeleye, S.I.; Akintemi, O.A.; Olasehinde, T.A. Moringa oleifera supplemented diet modulates nootropic-related biomolecules in the brain of STZ-induced diabetic rats treated with acarbose. Metab. Brain Dis. 2018, 33, 457-466. [CrossRef]

39. Oboh, G.; Adewuni, T.M.; Ademiluyi, A.O.; Olasehinde, T.A.; Ademosun, A.O. Phenolic constituents and inhibitory effects of Hibiscus sabdariffa L.(Sorrel) calyx on cholinergic, monoaminergic, and purinergic enzyme activities. J. Diet. Suppl. 2018, 15, 910-922. [CrossRef]

40. Oboh, G.; Ademosun, A.O.; Ogunsuyi, O.B.; Oyedola, E.T.; Olasehinde, T.A.; Oyeleye, S.I. In vitro anticholinesterase, antimonoamine oxidase and antioxidant properties of alkaloid extracts from kola nuts (Cola acuminata and Cola nitida). J. Complement. Integr. Med. 2018. [CrossRef]

41. Olasehinde, T.A.; Olaniran, A.O.; Okoh, A.I. Aqueous-ethanol extracts of some South African seaweeds inhibit beta-amyloid aggregation, cholinesterases, and beta-secretase activities in vitro. J. Food Biochem. 2019, 43, e12870. [CrossRef]

42. Olasehinde, T.A.; Mabinya, L.V.; Olaniran, A.O.; Okoh, A.I. Chemical characterization of sulfated polysaccharides from Gracilaria gracilis and Ulva lactuca and their radical scavenging, metal chelating, and cholinesterase inhibitory activities. Int. J. Food Prop. 2019, 22, 100-110. [CrossRef]

43. Olasehinde, T.A.; Mabinya, L.V.; Olaniran, A.O.; Okoh, A.I. Chemical characterization, antioxidant properties, cholinesterase inhibitory and anti-amyloidogenic activities of sulfated polysaccharides from some seaweeds. Bioact. Carbohydr. Diet. Fibre 2019, 18, 100182. [CrossRef]

44. Syad, A.N.; Rajamohamed, B.S.; Shunmugaiah, K.P.; Devi, P.K. Neuroprotective effect of the marine macroalga Gelidiella acerosa: Identification of active compounds through bioactivity-guided fractionation. Pharm. Biol. 2016, 54, 2073-2081. [CrossRef] [PubMed]

45. Rengasamy, K.R.; Amoo, S.O.; Aremu, A.O.; Stirk, W.A.; Gruz, J.; Šubrtová, M.; Doležal, K.; Staden, J.V. Phenolic profiles, antioxidant capacity, and acetylcholinesterase inhibitory activity of eight South African seaweeds. J. Appl. Phycol. 2015, 27, 1599-1605. [CrossRef]

46. Jung, S.H.; Young, U.M.; Inho, K.; Suengmok, C.; Daeseok, H.; Changho, L. In vitro screening for anti-dementia activities of seaweed extracts. J. Korean Soc. Food Sci. Nutr. 2016, 45, 966-997.

47. Rafiquzzaman, S.M.; Ki, E.Y.; Lee, J.M.; Mohibbullah, M.; BadrulAlam, M.; Moon, S.; Kim, J.M.; Kong, S. Anti-Alzheimers and anti-inflammatory activities of a glycoprotein purified from the edible brown alga Undaria pinnatifida. Food Res. Int. 2015, 77, 118-124. [CrossRef]

48. Shanmuganathan, B.; Sheeja, M.D.; Sathya, S.; Devi, P.K. Antiaggregation potential of Padina gymnospora against the toxic Alzheimer's beta-amyloid peptide 25-35 and cholinesterase inhibitory property of its bioactive compounds. PLoS ONE 2015, 10, e0141708. [CrossRef] 
49. Castro-Silva, E.S.; Bello, M.; Hernández-Rodríguez, M.; Correa-Basurto, J.; Murillo-Álvarez, J.I.; Rosales-Hernández, M.C.; Muñoz-Ochoa, M. Invitro and insilico evaluation of fucosterol from Sargassum horridum as potential human acetylcholinesterase inhibitor. J. Biomol. Struc. Dyn. 2018. [CrossRef]

50. Choi, B.W.; Lee, H.S.; Shin, H.; Lee, B.H. Multifunctional activity of polyphenolic compounds associated with a potential for Alzheimer's disease therapy from Ecklonia Cava. Phytother. Res. 2015, 29, 549-553. [CrossRef]

51. Sathya, M.; Premkumar, P.; Karthick, C.; Moorthi, P.; Jayachandran, K.S.; Anusuyadevi, M. BACE1 in Alzheimer's disease. Clin. Chim. Acta 2012, 24, 171-178. [CrossRef]

52. Cheng, X.; He, P.; Lee, T.; Yao, H.; Li, R.; Shen, Y. High activities of BACE1 in brains with mild cognitive impairment. Am. J. Pathol. 2014, 184, 141-147. [CrossRef] [PubMed]

53. Rockenstein, E.; Mante, M.; Alford, M.; Adame, A.; Crews, L.; Hashimoto, M.; Esposito, L.; Mucke, L.; Masliah, E. High $\beta$-secretase activity elicits neurodegeneration in transgenic mice despite reductions in amyloid- $\beta$ levels. J. Biol. Chem. 2005, 280, 32957-32967. [CrossRef] [PubMed]

54. Jung, H.A.; Ali, M.Y.; Choi, R.J.; Jeong, H.O.; Chung, H.Y.; Choi, J.S. Kinetics and molecular docking studies of fucosterol and fucoxanthin, BACE1 inhibitors from brown algae Undaria pinnatifida and Ecklonia stolonifera. Food Chem. Toxicol. 2016, 89, 104-111. [CrossRef] [PubMed]

55. Seong, S.H.; Ali, M.Y.; Kim, H.R.; Jung, H.A.; Choi, J.S. BACE1 inhibitory activity and molecular docking analysis of meroterpenoids from Sargassum serratifolium. Bioorg. Med. Chem. 2017, 25, 3964-3970. [CrossRef] [PubMed]

56. Wagle, A.; Seong, S.H.; Zhao, B.T.; Woo, M.H.; Jung, H.A.; Choi, J.S. Comparative study of selective in vitro and in silico BACE1 inhibitory potential of glycyrrhizin together with its metabolites, 18a-and 18b-glycyrrhetinic acid, isolated from Hizikia fusiformis. Arch. Pharm. Res. 2018, 41, 409-418. [CrossRef]

57. Dong, X.; Wang, Y.; Qin, Z. 2009. Molecular mechanisms of excitotoxicity and their relevance to pathogenesis of neurodegenerative diseases. Acta Pharm. Sin. 2009, 30, 379-387. [CrossRef]

58. Fernandes, F.; Barbosa, M.; Oliveira, A.P.; Azevedo, I.C.; Sousa-Pinto, I.; Valentão, P.; Andrade, P.B. The pigments of kelps (Ochrophyta) as part of the flexible response to highly variable marine environments. $J$. Appl. Phycol. 2016, 28, 3689-3696. [CrossRef]

59. Kim, J.J.; Kang, Y.J.; Shin, S.A.; Bak, D.H.; Lee, J.W.; Lee, K.B.; Yoo, Y.C.; Kim, D.K.; Lee, B.H.; Kim, D.W.; et al. Phlorofucofuroeckol improves glutamate-induced neurotoxicity through modulation of oxidative stress-mediated mitochondrial dysfunction in PC12 cells. PLoS ONE 2016, 11, 0163433. [CrossRef]

60. O’Brien, R.J.; Wong, B.C. Amyloid precursor protein processing and Alzheimer's disease. Annu. Rev. Neurosci. 2011, 34, 185-204. [CrossRef]

61. Giffin, J.C.; Richards, R.C.; Craft, C.; Jahan, N.; Leggiadro, C.; Chopin, T.; Szemerda, M.; MacKinnon, S.L.; Ewart, K.V. An extract of the marine alga Alaria esculenta modulates $\alpha$-synuclein folding and amyloid formation. Neurosci. Lett. 2017, 22, 87-93. [CrossRef]

62. Syad, A.N.; Devi, K.P. Assessment of anti-amyloidogenic activity of marine red alga G. acerosa against Alzheimer's beta-amyloid peptide 25-35. Neurol. Res. 2015, 37, 14-22. [CrossRef] [PubMed]

63. Alghazwi, M.; Smid, S.; Zhang, W. In vitro protective activity of South Australian marine sponge and macroalgae extracts against amyloid beta $\left(\mathrm{A} \beta_{1-42}\right)$ induced neurotoxicity in PC-12 cells. Neurotoxicol. Teratol. 2018, 68, 72-83. [CrossRef] [PubMed]

64. Gan, S.Y.; Wong, L.Z.; Wong, J.W.; Tan, E.L. Fucosterol exerts protection against amyloid $\beta$-induced neurotoxicity, reduces intracellular levels of amyloid $\beta$ and enhances the mRNA expression of neuroglobin in amyloid $\beta$-induced SH-SY5Y cells. Int. J. Biol. Macromol. 2019, 121, 207-213. [CrossRef] [PubMed]

65. Alghazwi, M.; Smid, S.; Karpiniec, S.; Zhang, W. Comparative study on neuroprotective activities of fucoidans from Fucus vesiculosus and Undaria pinnatifida. Int. J. Biol. Macromol. 2019, 122, 255-264. [CrossRef] [PubMed]

66. Yang, E.J.; Ahn, S.; Ryu, J.; Choi, M.; Choi, S.; Chong, Y.H.; Hyun, J.W.; Chang, M.; Kim, H.S. Phloroglucinol attenuates the cognitive deficits of the 5XFAD mouse model of Alzheimer's disease. PLoS ONE 2015, 10, e0135686. [CrossRef]

67. Wang, J.; Zheng, J.; Huang, C.; Zhao, J.; Lin, J.; Zhou, X.; Naman, C.B.; Wang, N.; Gerwick, W.H.; Wang, Q.; et al. Eckmaxol, a phlorotannin extracted from Ecklonia maxima, produces anti- $\beta$-amyloid oligomer neuroprotective effects possibly via directly acting on glycogen synthase kinase 3ß. ACS Chem. Neurosci. 2018, 9, 1349-1356. [CrossRef]

68. Oh, J.H.; Choi, J.S.; Nam, T. Fucosterol from an edible brown alga Ecklonia stolonifera prevents soluble amyloid beta-induced cognitive dysfunction in aging rats. Mar. Drugs 2018, 16, 368. [CrossRef] 
69. Lin, J.; Yu, J.; Zhao, J.; Zhang, K.; Zheng, J.; Wang, J.; Huang, C.; Zhang, J.; Yan, X.; Gerwick, W.H.; et al. Fucoxanthin, a marine carotenoid, attenuates $\beta$-amyloid oligomer-induced neurotoxicity possibly via regulating the PI3K/Akt and the ERK pathways in SH-SY5Y cells. Oxid. Med. Cell. Longev. 2017, 2017, 6792543. [CrossRef]

70. Zhao, X.; Zhang, S.; An, C.; Zhang, H.; Sun, Y.; Li, Y.; Pu, X. Neuroprotective effect of fucoxanthin on ß-amyloid induced cell death. J. Chin. Pharm. Sci. 2015, 24, 467-470.

71. Wei, H.; Gao, Z.; Zheng, L.; Zhang, C.; Liu, Z.; Yang, Y.; Teng, H.; Hou, L.; Yin, Y.; Zou, X. Protective effects of fucoidan on A $\beta 25-35$ and d-Gal-induced neurotoxicity in PC12 cells and d-Gal-induced cognitive dysfunction in mice. Mar. Drugs 2017, 15, 77. [CrossRef]

72. Sathya, R.; Kanaga, N.; Sankar, P.; Jeeva, S. Antioxidant properties of phlorotannins from brown seaweed Cystoseira trinodis (Forsskål) C. Agardh. Arab. J. Chem. 2017, 10, S2608-S2614. [CrossRef]

73. Li, Y.; Fu, X.; Duan, D.; Liu, X.; Xu, J.; Gao, X. Extraction and identification of phlorotannins from the brown alga, Sargassum fusiforme (Harvey) setchell. Mar. Drugs 2017, 15, 49. [CrossRef] [PubMed]

74. Yuan, Y.; Zhang, J.; Fan, J.; Clark, J.; Shen, P.; Li, Y.; Zhang, C. Microwave assisted extraction of phenolic compounds from four economic brown macroalgae species and evaluation of their antioxidant activities and inhibitory effects on $\alpha$-amylase, $\alpha$-glucosidase, pancreatic lipase and tyrosinase. Food Res. Int. 2018, 113, 288-297. [CrossRef] [PubMed]

75. Arulkumar, A.; Rosemary, T.; Paramasivam, S.; Rajendran, R.B. Phytochemical composition, in vitro antioxidant, antibacterial potential and GC-MS analysis of red seaweeds (Gracilaria corticata and Gracilaria edulis) from Palk Bay, India. Biocatal. Agric. Biotechnol. 2018, 15, 63-71. [CrossRef]

76. Kosanić, M.; Ranković, B.; Stanojković, T. Biological activities of two macroalgae from Adriatic coast of Montenegro. Saudi J. Biol. Sci. 2015, 22, 390-397. [CrossRef] [PubMed]

77. Alencar, D.B.; Carvalho, C.F.T.; Rebouças, R.H.; Santos, D.R.D.; Pires-Cavalcante, K.M.; Lima, R.L.; Baracho, B.M.; Bezerra, R.M.; Viana, F.A.; Vieira, R.H.; et al. Bioactive extracts of red seaweeds Pterocladiella capillacea and Osmundaria obtusiloba (Floridophyceae: Rhodophyta) with antioxidant and bacterial agglutination potential. Asian Pac. J. Trop. Med. 2016, 9, 372-379. [CrossRef] [PubMed]

78. Agregán, R.; Munekata, P.E.; Domínguez, R.; Carballo, J.; Franco, D.; Lorenzo, J.M. Proximate composition, phenolic content and in vitro antioxidant activity of aqueous extracts of the seaweeds Ascophyllum nodosum, Bifurcaria bifurcata and Fucus vesiculosus. Effect of addition of the extracts on the oxidative stability of canola oil under accelerated storage conditions. Food Res. Int. 2017, 99, 986-994.

79. Pinteus, S.; Silva, J.; Alves, C.; Horta, A.; Fino, N.; Inês, A. Rodrigues susana mendes rui pedrosa. cytoprotective effect of seaweeds with high antioxidant activity from the Peniche coast (Portugal). Food Chem. 2017, 218, 591-599. [CrossRef]

80. Chiboub, O.; Ktari, L.; Sifaoui, I.; López-Arencibia, A.; Batle, M.R.; Mejri, M.; Valladares, B.; Abderrabba, M.; Piñero, J.E.; Lorenzo-Morales, J. In vitro amoebicidal and antioxidant activities of some Tunisian seaweeds. Exp. Parasit. 2017, 183, 76-80. [CrossRef]

81. Hifney, A.F.; Fawzy, M.A.; Abdel-Gawad, K.M.; Gomaa, M. Industrial optimization of fucoidan extraction from Sargassum sp. and its potential antioxidant and emulsifying activities. Food Hydrocoll. 2016, 54, 77-88. [CrossRef]

82. Rajauria, G.; Foley, B.; Abu-Ghannam, N. Identification and characterization of phenolic antioxidant compounds from brown Irish seaweed Himanthalia elongata using LC-DAD-ESI-MS/MS. Innov. Food Sci. Emerg. Technol. 2016, 37, 261-268. [CrossRef]

83. Leyton, A.; Pezoa-Conte, R.; Barriga, A.; Buschmann, A.H.; Mäki-Arvela, P.; Mikkola, J.P.; Lienqueo, M.E. Identification and efficient extraction method of phlorotannins from the brown seaweed Macrocystis pyrifera using an orthogonal experimental design. Algal Res. 2016, 16, 201-208. [CrossRef]

84. Olasehinde, T.A.; Olaniran, A.O.; Okoh, A.I. Neuroprotective effects of some seaweeds against Zn-induced neuronal damage in HT-22 cells via modulation of redox imbalance, inhibition of apoptosis and acetylcholinesterase activity. Metab. Brain Dis. 2019. [CrossRef] [PubMed]

85. Olasehinde, T.A.; Olaniran, A.O.; Okoh, A.I. Phenolic composition, antioxidant activity, anticholinesterase potential and modulatory effects of aqueous extracts of some seaweeds on $\beta$-amyloid aggregation and disaggregation. Pharm. Biol. 2019, 57, 460-469. [CrossRef] [PubMed] 
86. Huang, C.; Wu, S.; Yang, W.; Kuan, A.; Chen, C. Antioxidant activities of crude extracts of fucoidan extracted from Sargassum glaucescens by a compressional-puffing hydrothermal extraction process. Food Chem. 2016, 197, 1121-1129. [CrossRef] [PubMed]

87. Palanisamy, S.; Vinosha, M.; Marudhupandi, T.; Rajasekar, P.; Prabhu, N.M. Isolation of fucoidan from Sargassum polycystum brown algae: Structural characterization, in vitro antioxidant and anticancer activity. Int. J. Biol. Macromol. 2017, 102, 405-412. [CrossRef] [PubMed]

88. Hifney, A.W.; Fawzy, M.A.; Abdel-Gawad, K.M.; Gomaa, M. Upgrading the antioxidant properties of fucoidan and alginate from Cystoseira trinodis by fungal fermentation or enzymatic pretreatment of the seaweed biomass. Food Chem. 2018, 269, 387-395. [CrossRef]

89. Gomaa, M.; Fawzy, M.A.; Hifney, A.F.; Abdel-Gawad, K.M. Use of the brown seaweed Sargassum latifolium in the design of alginate-fucoidan based films with natural antioxidant properties and kinetic modeling of moisture sorption and polyphenolic release. Food Hydrocoll. 2018, 82, 64-72. [CrossRef]

90. Khajouei, R.A.; Keramat, J.; Hamdami, N.; Delattre, C.; Laroche, C.; Gardarin, C.; Lecerf, D.; Desbrières, J.; Djelveh, G.; Michaud, P. Extraction and characterization of an alginate from the Iranian brown seaweed Nizimuddinia zanardini. Int. J. Biol. Macromol. 2018, 118, 1073-1081. [CrossRef]

91. Yao, Y.; Xiang, H.; You, L.; Cui, C.; Sun-Waterhouse, D.; Zhao, M. Hypolipidaemic and antioxidant capacities of polysaccharides obtained from Laminaria japonica by different extraction media in diet-induced mouse model. Int. J. Food Sci. Tech. 2017, 52, 2274-2281. [CrossRef]

92. Kazir, M.; Abuhassira, Y.; Robin, A.; Nahor, O.; Luo, J.; Israel, A.; Golberg, A.; Livney, Y.D. Extraction of proteins from two marine macroalgae, Ulva sp. and Gracilaria sp., for food application, and evaluating digestibility, amino acid composition and antioxidant properties of the protein concentrates. Food Hydrocoll. 2019, 87, 194-203. [CrossRef]

93. Mohibbullah, M.; Maqueshudul, M.; Bhuiyan, H.; Hannan, M.A.; Getachew, P.; Hong, Y.; Choi, J.; Choi, S.; Moon, S. The edible red alga Porphyra yezoensis promotes neuronal survival and cytoarchitecture in primary hippocampal neurons. Cell. Mol. Neurobiol. 2016, 36, 669-682. [CrossRef] [PubMed]

94. Rajauria, G.; Foley, B.; Abu-Ghannam, N. Characterization of dietary fucoxanthin from Himanthalia elongata brown seaweed. Food Res. Int. 2017, 99, 995-1001. [CrossRef] [PubMed]

95. Yu, J.; Lin, J.; Yu, R.; He, S.; Wang, Q.; Cui, W.; Zhang, J. Fucoxanthin prevents $\mathrm{H}_{2} \mathrm{O}_{2}$-induced neuronal apoptosis via concurrently activating the PI3-K/Akt cascade and inhibiting the ERK pathway. Food Nutr. Res. 2017, 61, 1304678. [CrossRef]

96. Mohibbullah, M.; Haque, M.N.; Khan, M.N.; Park, I.S.; Moon, I.S.; Hong, Y. Neuroprotective effects of fucoxanthin and its derivative fucoxanthinol from the phaeophyte Undaria pinnatifida attenuate oxidative stress in hippocampal neurons. J. Appl. Phycol. 2018. [CrossRef]

97. Syad, A.N.; Devi, P.K. Gelidiella acerosa protects against A $\beta$ 25-35-induced toxicity and memory impairment in Swiss Albino mice: An in vivo report. Pharm. Biol. 2017, 55, 1423-1435.

98. Um, Y.M.; Lim, D.W.; Son, H.J.; Cho, S.; Lee, C. Phlorotannin-rich fraction from Ishige foliacea brown seaweed prevents the scopolamine-induced memory impairment via regulation of ERK-CREB-BDNF pathway. $J$. Funct. Foods 2018, 40, 110-116. [CrossRef]

99. Choi, J.Y.; Mohibbullah, M.; Park, I.S.; Moon, I.S.; Hong, Y.K. An ethanol extract from the phaeophyte Undaria pinnatifida improves learning and memory impairment and dendritic spine morphology in hippocampal neurons. J. Appl. Phycol. 2018, 30, 129-136. [CrossRef]

100. Hu, P.; Li, Z.; Chen, M.; Sun, Z.; Ling, Y.; Jiang, J.; Huang, C. Structural elucidation and protective role of a polysaccharide from Sargassum fusiforme on ameliorating learning and memory deficiencies in mice. Carbohydr. Polym. 2016, 139, 150-158. [CrossRef]

101. Wang, X.; Yi, K.; Zhao, Y. Fucoidan inhibits amyloid- $\beta$-induced toxicity in transgenic Caenorhabditis elegans by reducing the accumulation of amyloid- $\beta$ and decreasing the production of reactive oxygen species. Food Funct. 2018, 9, 552-560. [CrossRef]

102. Lin, J.; Huang, L.; Yu, J.; Xiang, S.; Wang, J.; Zhang, J.; Yan, X.; Cui, W.; He, S.; Wang, Q. Fucoxanthin, a marine carotenoid, reverses scopolamine-induced cognitive impairments in mice and inhibits acetylcholinesterase in vitro. Mar. Drugs 2016, 14, 67. [CrossRef] [PubMed]

103. Xiang, S.; Liu, F.; Lin, J.; Chen, H.; Huang, C.; Chen, L.; Zhou, Y.; Ye, L.; Zhang, K.; Jin, J.; et al. Fucoxanthin inhibits $\beta$-amyloid assembly and attenuates $\beta$-amyloid oligomer-induced cognitive impairments. J. Agric. Food Chem. 2017, 65, 4092-4102. [CrossRef] [PubMed] 
104. Zhang, L.; Wang, H.; Fan, Y.; Gao, Y.; Li, X.; Hu, Z.; Ding, K.; Wang, Y.; Wang, X. Fucoxanthin provides neuroprotection in models of traumatic brain injury via the Nrf2-ARE and Nrf2-autophagy pathways. Sci. Rep. 2017, 7, 46763. [CrossRef] [PubMed]

105. Yang, E.J.; Mahmood, U.; Kim, H.; Choi, M.; Choi, Y.; Lee, J.; Cho, J.; Hyun, J.; Kim, Y.S.; Chang, M.; et al. Phloroglucinol ameliorates cognitive impairments by reducing the amyloid $\beta$ peptide burden and pro-inflammatory cytokines in the hippocampus of 5XFAD mice. Free Radic. Biol. Med. 2018, 126, 221-234. [CrossRef]

(C) 2019 by the authors. Licensee MDPI, Basel, Switzerland. This article is an open access article distributed under the terms and conditions of the Creative Commons Attribution (CC BY) license (http://creativecommons.org/licenses/by/4.0/). 